\title{
Implementation Of Multi Experts Multi Criteria Decision Making For Rehabilitation And Reconstruction Action After A Disaster
}

\author{
Agung Teguh Wibowo Almais, Moechammad Sarosa, Muhammad Aziz Muslim
}

\begin{abstract}
This article is aimed to propose a method which used Non-Numeric assessment that is Multi Experts Multi Criteria Decision Making (MEMCDM) in order to construct supporting decision system in composing rehabilitation and reconstruction action after disaster. Because in all this time "Perencanaan dan Pengendalian Penanganan Bencana (P3B)" surveyor team does not have clear standard criteria to execute the compiling rehabilitation and reconstruction action after disaster. Method Multi Experts Multi Criteria Decision Making (MEMCDM) step is to determine the alternative, assessment scale, criteria, criteria quality, criteria quality negation, criteria aggregation, and the qualification expert score. In the stage of expert qualification score for primary and secondary data is different. In secondary data, the qualification score is based on the usage of expert amount. Meanwhile, for secondary data, the expert qualification score is based on the criteria amount which is chosen by the user. Training data that has been processed using method Multi Experts Multi Criteria Decision Making (MEMCDM) can form a pattern system to assess damage and losses after natural disasters. There for it could facilitate a team of surveyors in assessing the damage and losses after natural disasters.
\end{abstract}

Index Terms - MEMCDM, Rehabilitation, Reconstruction, Training, Surveyors.

\section{INTRODUCTION}

$\mathrm{N}$ ature disaster is the disaster which is resulted by several occurrences caused by nature, such as earthquake, tsunami, volcano eruption, flood, drought, tornado and landslide [1]. Since 2004, nature disaster apparently becomes the unavoidable part in Indonesia. This begins with earthquake and tsunami in Nangroe Aceh Darussalam and Nias Island, North Sumatera, then, earthquake in DI Yogyakarta and Central Java in May 2006 and several nature disasters in 2007. Those

Manuscript received March 22, 2016. (Write the date on which you submitted your paper for review.) This work was supported in part by Electrical Engineering Department University of BrawijayaAgung Teguh Wibowo Almais is with the Electrical Engineering Department, Faculty of Engineering,Brawijaya University, Malang, Indonesia (email: agung.twa@gmail.com)

Moechammad Sarosa, was the Electrical Engineering Department, State Polytechnic of Malang, Indonesia (e-mail: rmsarosa@yahoo.com).

Muhammad Aziz Muslim is Electrical Engineering Department, Faculty of Engineering,Brawijaya University, Malang, Indonesia (email: muhazizm2@gmail.com) disaster occurrences demand the emergency response effort immediately and prevalently to all of the victims and affected territory including the recovery of society life and territory after disaster [1].

The success of "Perencanaan dan Pengendalian Penanganan Bencana (P3B)" team in recovery program after disaster is absolutely determined by the wellrecovery planning from accurate data and information [2]. The abundant of problems in the area are caused by inaccurate the occupied data. When in the beginning of data collection, the criteria which is used by the surveyor in the field is perceived differently, so that in categorizing the available data will be different. So as a problem appears, the disaster data which is retrieved by "Badan Penanggulangan Bencana Daerah (BPBD)", province becomes different from the real condition in the field, because the data collection of damage type and loss after disaster used by the surveyor is differently perceived.

By using Multi Experts Multi Criteria Decision Making (MEMCDM), it is expected to simplify surveyor in the field in composing rehabilitation and reconstruction action after disaster later, because this system did not use complicated calculation but NonNumeric assessment [3]. Therefore, the research and development of a supporting decision system by using Multi Experts Multi Criteria Decision Making (MEMCDM) method is necessary [4]. So as this system is expected to be supporting decision tool for the related institution especially for the manager as the decisiontaking principle.

\section{THE PROPOSED METHOD}

The supporting decision is the approach or methodology to support decision-taking by using Computer Based Information System (CBIS). This research proposes supporting decision system method with Multi Experts Multi Criteria Decision Making (MEMCDM) method.

\section{A. Supporting Decision System}

Supporting Decision System (DSS) is defined as a system which is used to support the managerial decision taker in a semi-structured decision situation, but this does not mean to replace their assessment role. There is lso a definition which declares the supporting decision system as a computer based-system consisting of components, namely language system, knowledge, and 
problem processing system which interacts one to another [5].

\section{B. Fuzzy Multiple Attribute Decision Making}

Fuzzy Multiple Attribute Decision Making (FMAD) [6] is a method which is used to search for the optimal alternative from several alternatives with certain criteria. The point of Fuzzy Multiple Attribute Decision Making (FMAD) is to determine the quality score for every attribute, then, it continues with the classification process that will select the given alternative. Basically, there are 3 approaches to search for the attribute quality score, namely subjective, objective and the integration of subjective and objective approach.

Each of the approaches has strength and weakness. In the subjective approach, the quality score is determined based on subjectivity from the decisiontaker, so that some of the factors in classification alternative process can be freely determined. Meanwhile, in objective approach, the quality score is calculated mathematically, so that it ignores the subjectivity from decision-taker. There are some methods which can be used to solve the problem FMADM, as provided below:

1. Simple Additive Weighting (SAW) [9].

2. Weighted Product (WP) [12].

3. Elimination and Choise Expressing Reality (ELECTRE) [10].

4. Technique for Order Preference by Similarity to Ideal Solution (TOPSIS) [9].

5. Analytic Hierarchy Process (AHP) [11].

6. Multi Experts Multi Criteria Decison Making (MEMCDM) [3].

\section{Multi Experts Multi Criteria Decison Making} (MEMCDM)

The calculation step of Multi Experts Multi Criteria Decision Making (MEMCDM) method is below [7]:

- Determining the alternative and the criteria used.

- Making assessment scale.

- Analyzing statistic data (disaster data).

- Determining priority level each of criteria is based on alternative used.

- Making the assessment criteria matrix of data analysis result statistic and its alternative.

- Determining the negation score for every criterion based on the alternative used with the formula

$$
\operatorname{Neg}\left(\mathcal{W}_{a k}\right)=\mathcal{W}_{q}
$$

- Making the aggregation score for every criterion based on alternative used with the formula

$$
\mathcal{V}_{i j}=\min \left[\operatorname{Neg}\left(\mathcal{W}_{a k}\right) \vee V_{i j}\left(a_{k}\right)\right] \ldots . .(2)
$$

- Obtaining the aggregation result for every criterion.

- Doing the aggregation process every statistic data result based on alternative used with the formula

$$
\mathcal{Q}_{k}=\operatorname{Int}\left[1+\left(k * \frac{q-1}{r}\right)\right]
$$

\section{COMPOSING REHABILITATION AND \\ RECONSTRUCTION ACTION USING MULTI \\ EXPERTS MULTI CRITERIA DECISION MAKING (MEMCDM)}

This chapter explains the steps in preparing the data. This step covers the qualification and criteria assessment data processing like aggregation process, measurement method, and measurement result, the training and testing data accuracy used Multi Experts Multi Criteria Decison Making (MEMCDM).

\section{A. The Data Used}

There are two types of data in composing Supporting Decision System (DSS) rehabilitation and reconstruction action, namely training and testing data. In training data execute analysis process toward data sample after disaster 2010 which result in the pattern from the system, and it is constructed by using Multi Experts Multi Criteria Decison Making (MEMCDM) method. In the step of testing, used data sample after the disaster of 2011 and 2013.

\section{- Training data}

It has the function to form the system pattern and it can be a reference for how the data will be formed its pattern.

- Testing data

In the research, the type of the data which is used is the after disaster data in 2011 and 2013 as seen in TABLE I consisting of damage and loss data in East Java Province. Meanwhile, for the data accuracy needs the structured and understandable data. The after disaster data which is used is the secondary data in 2011 and 2013 from BPBD East java Province.

\section{TABLE I: THE EXAMPLE OF TESTING DATA WHICH USED IN EXPERIMENT}

\begin{tabular}{|l|c|c|}
\hline Criteria Name & Disaster Type & Sector Type \\
\hline $\begin{array}{l}\text { The residence is } \\
\text { flooded } 1 \mathrm{~m}- \\
1,5 \mathrm{~m}\end{array}$ & Flood & Residence \\
\hline $\begin{array}{l}\text { The dike is } \\
\text { broken-down }\end{array}$ & Flood & Infrastructure \\
\hline $\begin{array}{l}\text { The dike is } \\
\text { broken-down }\end{array}$ & Flood & Infrastructure \\
\hline $\begin{array}{l}\text { The road dike is } \\
\text { landslide } 100 \\
\text { meter }\end{array}$ & Flash flood & Infrastructure \\
\hline
\end{tabular}

(Source: The Disaster Data Analysis Result 2011 dan 2013)

\section{B. The Determination Process of Criteria and Alternative}

The step that is done before by Supporting Decision System (DSS) is the pre-processing to look for the criteria references which determine the damage type and loss after the nature disaster to training data and testing data. This process must be done because the used criteria by the entire user must be the same. The writer experienced difficulty in understanding the content of the after disaster data before doing the preprocessing. 
TABLE II: CRITERIA DATA

\begin{tabular}{|l|l|}
\hline Criteria code & Criteria name \\
\hline K001 & The building condition \\
\hline K002 & $\begin{array}{l}\text { The structure of the building } \\
\text { condition }\end{array}$ \\
\hline K003 & $\begin{array}{l}\text { The Physical condition of the } \\
\text { building damage }\end{array}$ \\
\hline K004 & The function of the building \\
\hline K005 & Other supporting condition \\
\hline $\begin{array}{l}\text { Source: The After Disaster Data BPBD East Java, 2010, 2010, 2013 } \\
\text { and General Director of Cipta Karya, DPU, 2006, The House } \\
\text { Technical And Building Anti-Earth Quake Guidance) }\end{array}$
\end{tabular}

TABLE III: ALTERNATIVE DATA

\begin{tabular}{|l|l|}
\hline $\begin{array}{l}\text { Alternative } \\
\text { code }\end{array}$ & Alternative name \\
\hline ALT001 & The damage type \\
\hline ALT002 & The amount of aid \\
\hline ALT003 & $\begin{array}{l}\text { The type of action or effort that } \\
\text { should do }\end{array}$ \\
\hline
\end{tabular}

TABLE IV: SECTOR AND SUB-SECTOR

\begin{tabular}{|l|l|}
\hline Sector name & The sub-sector name \\
\hline Economics & Farming \\
\cline { 2 - 2 } & Shopping complex \\
\cline { 2 - 2 } & Fishery \\
\cline { 2 - 2 } & Farming \\
\cline { 2 - 2 } & Market \\
\hline Social & Residence infrastructure \\
\cline { 2 - 2 } & Residence \\
\hline \multirow{5}{*}{ Infrastructure } & Other institution \\
\cline { 2 - 2 } & Health \\
\cline { 2 - 2 } & Religion (Mushola) \\
\cline { 2 - 3 } & Religion (Mosque) \\
\cline { 2 - 2 } & Education \\
\cline { 2 - 3 } & $\begin{array}{l}\text { Clean water and Sanitation } \\
\text { (Production) }\end{array}$ \\
\cline { 2 - 3 } & Energy (electricity) \\
\cline { 2 - 3 } & Other interconnection (Train) \\
\cline { 2 - 3 } & Water resources (dike) \\
\cline { 2 - 3 } & Water resources (Irrigation) \\
\hline & Telecommunication \\
\hline Cross sector & $\begin{array}{l}\text { Government and private office } \\
\text { complex Perkantoran }\end{array}$ \\
\cline { 2 - 2 } & Financial and banking \\
\hline
\end{tabular}

(Source: After Disaster Data Analysis 2010 and 2013)

The first thing in processing after disaster data is to break the after disaster data to address, criteria, type of disaster, the amount of aid, and the action or the effort that has been done. In the TABLE II above is the reference criteria after the disaster which is made by the government. The criteria are the supporting decision system formation [8].

In the TABLE III above is the alternative data of after disaster data analysis result of "Badan Penanggulangan Bencana Daerah (BPBD)" East Java in 2010, 2011 and 2013. From those three alternatives, the most determination alternative is the type of damage, because if the type of damage has been known, then, the amount of aid and the action type or effort that should do will also be known.

Rehabilitation and reconstruction are the actions to repair or recover the society physical and non-physical activity which is affected by the after disaster. Related to TABLE IV which will be explained, there are 5 sectors and each of sectors has sub-sector.

\section{The Qualification and Assessment Criteria Process}

The qualification and assessment process is the most important to look for the score from each criterion based on the available alternative. The problem rises when qualification is the reference e the quality and score which have to be used to qualify and assess every criterion. This thing can cause the writer experience difficulties in determining the quality and score which is used so it demands the thorough observation.

In TABLE $\mathrm{V}$ has been determined that the qualification and assessment criteria are made based on the General Director of Cipta Karya data "Dinas Pekerjaan Umum (DPU)'”.

TABLE V: QUALIFICATION AND SCORE SCALE

\begin{tabular}{|c|c|c|c|}
\hline No. & Criteria & Quality & Score \\
\hline \multirow[t]{3}{*}{1.} & \multirow[t]{3}{*}{$\begin{array}{l}\text { The building } \\
\text { condition }\end{array}$} & Light & $\begin{array}{l}\text { Remain } \\
\text { Standing }\end{array}$ \\
\hline & & Medium & Skew \\
\hline & & Heavy & $\begin{array}{c}\text { Totally } \\
\text { Collapse }\end{array}$ \\
\hline \multirow[t]{3}{*}{2.} & \multirow[t]{3}{*}{$\begin{array}{l}\text { The structure of } \\
\text { building condition }\end{array}$} & Light & $\begin{array}{l}\text { In some } \\
\text { Parts, there is } \\
\text { light damage }\end{array}$ \\
\hline & & Medium & $\begin{array}{l}\text { Partial light } \\
\text { damage }\end{array}$ \\
\hline & & Heavy & $\begin{array}{l}\text { Partial light } \\
\text { damage }\end{array}$ \\
\hline \multirow[t]{3}{*}{3.} & \multirow{3}{*}{$\begin{array}{l}\text { Physical building } \\
\text { condition heavy } \\
\text { damage }\end{array}$} & Light & $<30 \%$ \\
\hline & & Medium & $30-50 \%$ \\
\hline & & Heavy & $>50 \%$ \\
\hline \multirow[t]{3}{*}{4.} & \multirow[t]{3}{*}{$\begin{array}{l}\text { The function of } \\
\text { the building }\end{array}$} & Light & $\begin{array}{c}\text { Not } \\
\text { dangerous }\end{array}$ \\
\hline & & Medium & $\begin{array}{l}\text { Relatively } \\
\text { dangerous }\end{array}$ \\
\hline & & Heavy & $\begin{array}{c}\text { Very } \\
\text { dangerous }\end{array}$ \\
\hline \multirow[t]{3}{*}{5.} & \multirow[t]{3}{*}{$\begin{array}{l}\text { Other supporting } \\
\text { condition }\end{array}$} & Light & $\begin{array}{c}\text { Partial light } \\
\text { damage }\end{array}$ \\
\hline & & Medium & $\begin{array}{l}\text { Partial light } \\
\text { damage }\end{array}$ \\
\hline & & Heavy & $\begin{array}{l}\text { Totally } \\
\text { damage }\end{array}$ \\
\hline
\end{tabular}

(Source: After Disaster Data Analysis 2010 and 2013)

D. Aggregation Criteria Process $\left(\mathcal{V}_{i j}\right)$ and Score Quality $\left(Q_{k}\right)$ Multi Experts Multi Criteria Decision Making (MEMCDM)

The Multi Experts Multi Criteria Decision Making (MEMCDM) method is used to determine the aggregation criteria, score quality, and statistic data 
aggregation. To criteria aggregation can be done for every criterion based on the used alternative with the formula (1). To look for the variable quality score $k$ can be replaced with the amount of chosen criteria by the user.

\section{E. The Data Plot}

The data plot process explains about how the data plot works by using Multi Experts Multi Criteria Decision Making (MEMCDM) method and the experiment data plot. For clear explanation can be seen in Fig.1.

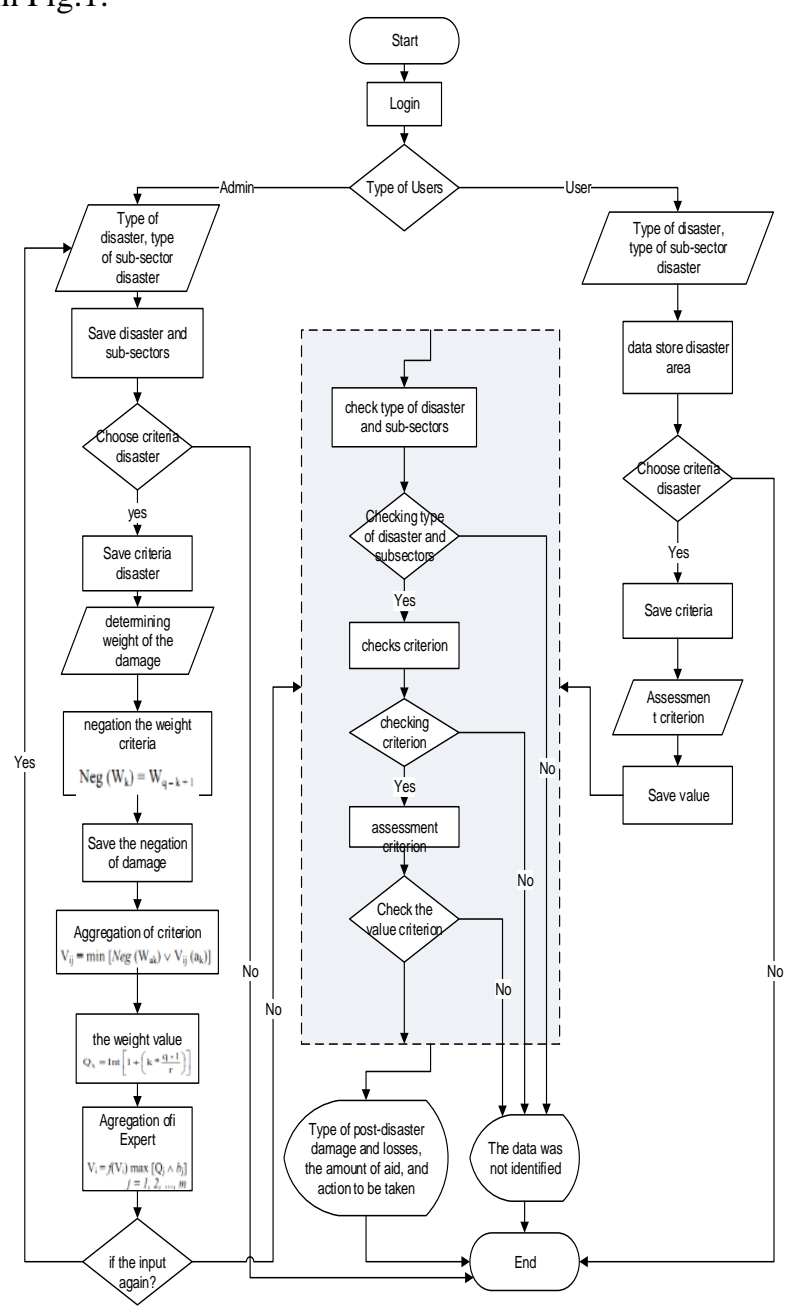

Fig. 1 The Data Plot in System

\section{F. Accuracy Experiment}

In the research with training data in the amount of 36 after disaster 2010 data which refer to the Multi Experts Multi Criteria Decision Making (MEMCDM) results in accuracy to the Multi Experts Multi Criteria Decision Making (MEMCDM) method in the amount of 97, 22\%. As seen in Fig. 2 and Fig. 3 which illustrate the quantity the training data which is used to each of method. To testing data in the quantity of 123 after disaster 2011 and 2013 data which refer to the Multi Experts Multi Criteria Decision Making (MEMCDM) result in accuracy to the Multi Experts Multi Criteria Decision Making (MEMCDM) method in the amount of $73,13 \%$, as in the Fig. 4 and Fig. 5 which illustrate the quantity the training data which is used to each of method.
Data Accuracy training

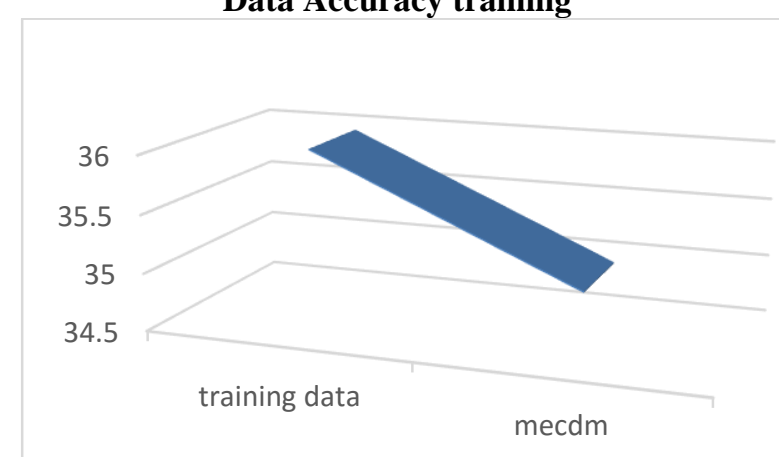

Fig. 2 Graph data accuracy training

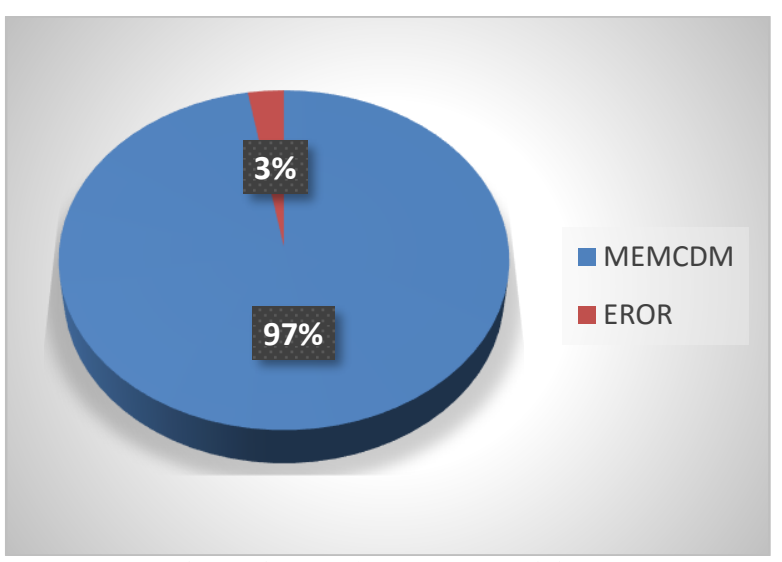

Fig. 3 Diagram data accuracy training

Data Accuracy testing

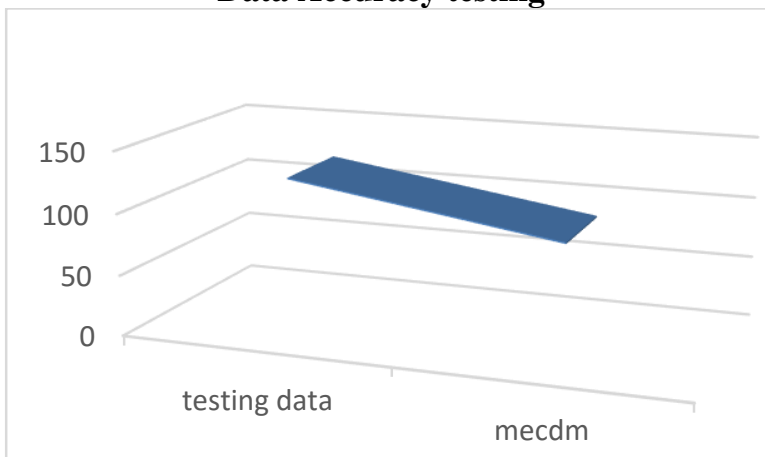

Fig. 4 Graph data accuracy testing

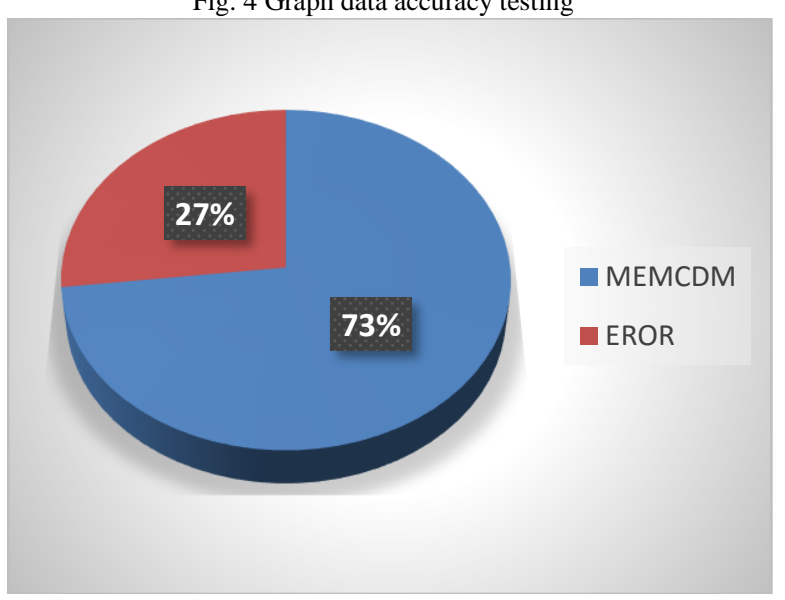

Fig. 5 Diagram data accuracy testing 


\section{IV.CONCLUSION AND FUTURE WORK}

One of the calculation step in Multi Experts Multi Criteria Decision Making (MEMCDM) is the expert qualification score, in this research, the experts qualification score used the criteria amount which is chosen by the user because if it uses the experts amount, then, it has to use the primary data. However, in this research the used data is secondary data. For training data the accuracy is $97 \%$ with the use of Multi Experts Multi Criteria Decision Making (MEMCDM) method. Meanwhile, for testing data, the accuracy is $73 \%$ with the use of Multi Experts Multi Criteria Decision Making (MEMCDM).

There are also suggestions to give in this research to further development, so that it can improve the quality and functionality of this supporting decision system method, as provided below:

1. Using more training data to produce better testing accuracy data.

2. This research is a supporting decision system which uses Multi Experts MultiCriteria Decision Making (MEMCDM) method. So in the next research, it can be developed with the other supporting decision system, such as Weighted Product (WP), Simple Additive Weighting (SAW), Elimination and Choise Expressing Reality (ELECTRE), Technique for Order Preference by Similarity to Ideal Solution (TOPSIS), and Analytic Hierarchy Process (AHP).

\section{REFERENCES}

[1] Anonim, P. T.,'Penilaian Kerusakan dan Kerugian,' BAPPENAS,Jakarta, 2008.

[2] Anonim. ,'Ruu Penanggulangan Bencana : Perlu Diatur Kriteria Bencana \& Kewenangannya," Pusat Komunikasi Publik,2006.

[3] Hadiguna, K. I., Delati, A., \& Reed, R.,'Implementing a webbased decision support system for disaster logistics: A case study of an evacuation location assessment for Indonesia," International Journal of Disaster Risk Reduction, 38-47, 2014.

[4] Nurhasanah, N.,"Penetuann Prioritas Alternatif Kebijakan Sistem Produksi Berdasarkan Pendekatan Non Numeric Multi Experts Multi Criteria Decision Makin:Studi Kasus PT X,' INASEA, 2006.

[5] Turban, E.,'Decision Support System and Intelligent System," Yogyakarta: Andi Offset, 2005.

[6] Wei, G.-W.,"GRA method for multiple attribute decision making with incomplete weight information in intuitionistic fuzzy setting original research article," Knowledge-Based Systems, 2010.

[7] Yager, R.,"Non-numeric multi-criteria multi-person decision mak-ing," Kluwer Academic Publishers, 81 - 93, 1993.

[8] Suryadi, k., \& Ramdhani, A.,"Sistem Pendukung Keputusan, Suatu Wacana Struktural Idealisasi dan Implementasi Konsep Pengambilan Keputusan," Bandung: PT. Remaja Rosdakarya Bandung, 1998.

[9] Ontah, G. M., \& Rindengan, A. J.,"Sistem Pendukung Keputusan Dalam Memetakan Wilayah Risiko Banjir," JdC, Vol.3, No. 2, (pp. 24-29), 2014.

[10] Putra, A. A., Andreswari, D., \& Susilo, B.,"Sistem Pendukung Keputusan Untuk Penerima Bantuan Pinjaman Samisake Dengan Metode Electre (Studi Kasus: LKM Kelurahan Lingka Timur Kota Bengkulu)," Jurnal Rekursif, Vol. 3 No. 1, 2015.

[11] Putri, A. P., Utama, M. S., Rachmania, R. N., \& Soesanto, R. P., "Perancangan Sistem Pendukung Keputusan dan Sistem Informasi Geografis Pemberian Bantuan Korban Banjir di Kabupaten Bandung Selatan," Seminar Nasional IENACO, (pp.318-326), 2014.

[12] Lestari, S., "Penerapan Metode Weighted Product Model Untuk Seleksi Calon Karyawan," Jurnal Sistem Informasi (JSI),VOL. 5, NO. 1, April 2013.
Agung Teguh Wibowo Almais has received Bachelor Degree in Information Technology, Islamic United State Maulana Malik Ibrahim Malang, Indonesia, (2004-208). M.T student (2014- tell now) in Electrical Engineering Department, Faculty of Engineering,Brawijaya University, Malang, Indonesia

Fields of interest: Decision Support System, web-based system and related fields.

Moechammad Sarosa has received Bachelor Degree, Universite De Nancy I, 1990. Master Degree, Bandung Institute Technology Bandung, 2002. PHD Degree, Bandung Institute Technology, 2007. Science Lecturer Electrical Engineering Department, State Polytechnic of Malang till now.

Muhammad Aziz Muslim has received Bachelor Degree, Brawijaya University, 1995. Master Degree, Surabaya Institute Technology, 2001. PHD Degree, Kyushu Institute of Technology. Chairman of Electrical Engineering Department, Faculty of Engineering, Brawijaya University, Malang, Indonesia. Science Lecturer Brawijaya University. Under-graduate and postgraduate Electrical Engineering Department, Faculty of Engineering, Brawijaya University till now. 